\title{
Dynamic Response of Risk Management Model to Mitigate Impact of Maritime Regulatory Changes: Oil Tanker Owners Perspective
}

\author{
Pratomo Setyohadi \\ Faculty of Marine Technology \\ Institut Teknologi Sepuluh Nopember, Kampus ITS Sukolilo, Surabaya 60111, Indonesia \\ E-mail: pratomosetyohadi2015@gmail.com (Corresponding Author) \\ K.B. Artana \\ Faculty of Marine Technology \\ Institut Teknologi Sepuluh Nopember, Kampus ITS Sukolilo, Surabaya 60111, Indonesia \\ E-mail: ketutbuda@its.ac.id \\ Djauhar Manfaat \\ Faculty of Marine Technology \\ Institut Teknologi Sepuluh Nopember, Kampus ITS Sukolilo, Surabaya 60111, Indonesia \\ R.O.S. Gurning \\ Faculty of Marine Technology \\ Institut Teknologi Sepuluh Nopember, Kampus ITS Sukolilo, Surabaya 60111, Indonesia \\ E-mail: sautg@its.ac.id
}

\begin{abstract}
The contemporary shipping industry is a high-risk business activity that is highly regulated by the International Maritime Organization (IMO). Changes in IMO regulations are often triggered by major incidents that bring safety at sea into public view. They may address ship instruments, operation, cargo, crew, environment, security and safety, and can generate higher Capital Expenses (CAPEX) and Operational Expenses (OPEX) for shipping businesses. Oil tanker owners are key stakeholders in the shipping industry and are most exposed to the risk of higher on-cost expenses both for CAPEX and OPEX. Between 2006 and 2019, regulations regarding oil tankers were changed six to seven times per year. This paper assesses the financial impact of changes in major international maritime regulations, primarily, the International Convention of Safety of Life at Sea (SOLAS), MARPOL, and STCW. The methodology involves using a risk matrix from a specific company and combining it with system dynamics to forecast the dynamic effect of such changes on the oil tanker market. The result shows that changes in regulations can have a catastrophic impact on the sustainability of the oil tanker business.
\end{abstract}

Keywords: international maritime regulation; risk assessment; shipping industry; system dynamics; oil tanker; oil tanker owner

\section{INTRODUCTION}

The International Maritime Organization (IMO) is the only international regulatory body for safety affairs in the maritime industry, and is directly concerned with promoting quality in the shipping industry, particularly, through the prevention of marine accidents or sea pollution (Mitroussi, 2004). The shipping industry has been alert to potential marine disasters ever since the sinking of the Titanic in 1912. On several occasions, a tragic accident has raised international safety issues and led to the development of major international conventions. The International Convention of Safety of Life at Sea (SOLAS) was the first international treaty concerning the safety of ships. The first version of this regulation was adopted in 1914 in response to the Titanic disaster. Although safety remains IMO's most important responsibility, the new problem of pollution has emerged as significant.

The growth of the shipping industry in the late 1960s especially in oil tankers, and the Torrey Canyon disaster of 1967, where 120,000 tons of oil was spilled into the sea, raised serious concerns. Consequently, IMO introduced a series of measures to prevent tanker accidents and minimize their consequences. The most important measure was the International Convention for the Prevention of Pollution from Ships, 1973 as modified by the Protocol of 1978 relating thereto (MARPOL 73/78). Other regulations have also extended this concern to the design and structure of ships. In 1989 the tanker "Exxon Valdez" ran aground in the pristine waters of Alaska's Prince William Sound and spilt 10 million gallons, or about $20 \%$ of its cargo of crude oil. The primary cause of the incident was groundings, and, thus, the IMO committee concluded that the most cost-effective design to prevent major oil spills was a double-skinned hull Two major initiatives were also established that extended safety and security to human elements. In July 1998, the International Safety Management Code (ISM) came into 
force, and in July 2004, a new, comprehensive security regime for international shipping, including the International Ship and Port Facility Security (ISPS) Code (made mandatory under amendments to SOLAS adopted in 2002) was initiated in response to increasing concerns about security after the tragic September 11 terrorist attack.

These regulations and initiatives have definitely reduced the number of marine accidents (Eliopoulu \& Mikelis, 2015). However, they have also affected how the shipping industry is perceived within the international maritime regime. Research conducted in 1982 by Abrahamson found a shift from "how does the environment affect the ships?" to "how does the ship affect the environment". This change from the environment to the ship as the main focus for regulating safety and security at sea means that shipping companies have to increase their capital base, make new investments and disclose more information about their operations. (Grammenos \& Choi, 2014). One area of shipping management that is most profoundly affected is shipping finance.

In the study of maritime regulations, researchers have mainly focused on their impact on safety at sea, pollution, and performance analysis. There has been little research on their financial impact on the shipping industry, particularly in regard to managing the risk of changes to maritime regulations that may be quite excessive (Karahalios, 2015). It has been challenging for many private organisations of the shipping industry to develop their business in such a regulatory climate (Klikauer \& Morris, 2003; Neser, et al., 2008; Progoulaki \& Theotokas, 2010; Tsai, et al, 2009). Whilst such regulations are important, they have imposed significant changes upon the ship operators. The shipping business is important; ships are now involved in roughly $90 \%$ of global trade. the global shipping industry generates an annual income of almost USD500 billion in freight rates, representing approximately $5 \%$ of the total global economy (Albertjin, et al., 2011). In turn, levels of capital investment are also very high; modern vessels are sophisticated assets that often require more than USD150 million to build, depending on type and size.

This study focused on the oil tanker business because it is a major stakeholder in the shipping industry. Table $\mathbf{1}$ illustrates that dry bulks has $34 \%$ total volume of world seaborne trade is dry bulk consisting of iron ore, coal, grain, bauxite and alumina and phosphate rock. However, the biggest cargo type transported in the world, and by oil tankers, is fossil fuel at $26 \%$ of total volume of world seaborne trade.

Table 1 World Seaborne Trade in 2014 based on types of cargo

\begin{tabular}{|c|c|c|}
\hline Cargo type & $\begin{array}{c}\text { Million } \\
\text { tones }\end{array}$ & Percentage \\
\hline Chemicals & 295,251 & $3 \%$ \\
\hline Gas & 295,251 & $3 \%$ \\
\hline Fossil Fuel & 2558,842 & $26 \%$ \\
\hline Container & 1476,255 & $15 \%$ \\
\hline Other (minor bulk \& other) & 1869,923 & $19 \%$ \\
\hline $\begin{array}{l}\text { Five main dry Bulks (iron ore, } \\
\text { coal, grain, bauxite and alumina \& } \\
\text { phosphate rock) }\end{array}$ & 3346,178 & $34 \%$ \\
\hline Total & 9841,7 & $100 \%$ \\
\hline
\end{tabular}

Source: Review of Maritime Transports, 2015
Researchers have argued that the maritime industry is overregulated, and is even one of the most heavily regulated industries (as discussed in Karahalios, 2015; Alderton \& Leggate, 2005; Alizadeh, et al, 2015; Horn, et al, 2008). Although, many people agree that the IMO should increase safety standards at the sea, the costs for private stake holders that are generated by changes in regulations are also significant. These costs include the expenses necessary to conform to existing regulations as well as preparing for forthcoming measures. Deadlines for the implementation of regulations can be challenging to meet when they overlap with the long recession periods occasionally generated by unpredictable marker cycles. The average time between adoption and entry into force has been calculated as 3.1 years (Knapp \& Franses, 2009). Moreover, the interest of ship owners to comply with regulations is much narrower than that of the states. Consequently, ship owners will usually encounter a conflict of interest between controlling their clients and retaining their market share. Their willingness to contribute regulatory changes depends on the benefits they can gain in relation to the significant cost that they will bear in implementing the standards (Karahalios, 2015), particularly given that the shipping industry will require more capital in the near future due to aging fleets and higher safety standards (Albertjin, et al., 2011).

\section{METHODOLOGY}

Regulatory changes raise many questions in the context of assessing their impact on the shipping industry such as: Do they incur a risk to the business community, especially from the perspective of the owners of oil tankers? How do we measure their effect as a form of financial risk? How can their impact on company revenue be modelled? How do we forecast the future impact of these changes in tanker market? New tools and solutions are needed to evaluate the impact of implementing changes to IMO regulations, particularly if they are understood as risks. Established principles such as risk analysis, knowledge management and cost evaluation. (Karahalios, 2015) can be utilized as management tools. This study uses a risk assessment approach as a method to assess the financial impact of changes in IMO regulations, especially regarding oil tankers. Risk assessment methods are widely used in various areas of research (for example, Soares \& Teixira (2001); Wang (2006); Rigaud, et al (2012). However, they have not been specifically used in relation to the shipbuilding industry and rarely to discuss the financial impact of regulatory changes. Yet, stakeholders in the shipping industry need to adopt new tools in order to quantify the risk and implement new approaches to fund capital budgeting (Albertjin, et al., 2011).

This study also uses a system dynamic simulation to forecast the impact of changes to maritime regulation. This method has been used in various forms of research when the focus is very complex; it is, thus, an effective means for modeling the impact of regulatory changes because variables are correlative with time. System dynamics can enable stakeholders, such as the owners of tanker ships to develop mitigation strategies for effectively implementing changes to regulations. Empirical analysis is conducted by exploring data obtained from the publication of the ABS (American Bureau of Shipping) in 2015. This data set contains 834 changes to IMO's maritime regulations (SOLAS, MARPOL, 
Load line, STCW and BWM) for the period from 2006 to 2019. It includes specific information for each regulatory requirement, including ship type, size parameter, age of ships, and compliance date. We isolated 125 regulatory changes directly related to tanker ships, while only 83 regulations were mandatory and required ship owner to comply. The data collection was complemented with a questionnaire, observation and interviews with experts in financing the tanker shipping industry.

\subsection{Risk Management Approach}

Shipping has also always been a volatile business, subject to extreme changes in revenues, operating cash flows and asset values. Risk assessment involves two factors: the probability of its occurrence and the consequences of its materialization (Ben-Asher, 2008; Androu, et al., 2014; Song \& Panayides, 2012; Grammenos, 2010). The risk management technique for this study consists of five steps to assess the impact of the regulatory change;

Step (1) Identify the impact area. According to Leggate, et al., (2005) changes in maritime regulations can have an impact on five areas, which are Ship Instrument/Construction, Ship Operation, Cargo Ship, Crew/person onboard, Environment and Security.

Step (2) Determine the consequence. Each change is analyzed by estimating the implementation costs from interviews with experts in shipping finance. The financial impact expended by the shipping company/owner is then calculated to obtain the total cost of implementation. In application, the determined implementation cost is multiplied by the number of tanker fleet owned by the company and the total annual costs for their maintenance and service. This will help to determine the consequence criteria in the risk matrix.

Step (3) Determine the frequency/likelihood: The average number of changes to regulations that occur each year is calculated. This figure is determined by dividing the total changes within the period from 2006-2019.

Step (4) Define risk: Risk assessment is conducted by using the risk matrix used by thecompany chosen as a case study

Step (5) Establish acceptable level of risk: This step is to represent all the risk assessment for the attribute in the decision matrix by case company

\subsection{System Dynamics Modelling and Simulation Approach}

System-dynamics is a structural system with an architecture that incorporates cause and causality relations and provides a user-friendly interface for conducting sensitivity analyses (Sterman, 2004). Furthermore, it does not require external calculations and can incorporate assessments of several external variables, such as changes in the demand for oil and in new building costs, and several fundamental relationships, such as the rate of the construction lag or the pace at which the system reaches equilibrium.

The first step is to modelize correlations between each variable by using a causal loop diagram, as this method can visualize the relationships between different variables in a system. The diagram consists of a set of nodes and edges. Nodes represent the variables and edges represent a connection or a relation between the two variables. A link marked positive indicates a positive relationship, and a link marked negative indicates a negative relationship. A positive causal link means the two nodes change in the same direction, i.e. if the node in which the link starts decreases, the other node also decreases. Similarly, if the node in which the link starts increases, the other node increases as well.

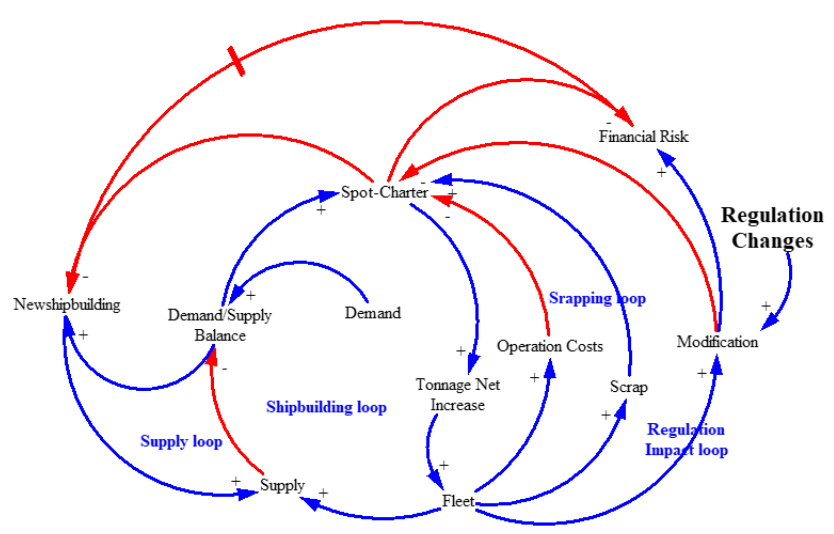

Figure 1 Causal loop diagram mitigation scenario impact of IMO regulatory changes on tankers industry

A negative causal link means the two nodes change in opposite directions, i.e. if the node in which the link starts increases, the other node decreases and vice versa showed causality process. Moreover, causal loop diagram useful to describe relation between variable involved in the system and relation effect in one system with another. The arrow marked positive that indicate equal relation, where if there is additional value on variable will increase the variable affects. The arrow marked negative showed inverse relation, where there is additional value will lead to reduction in the variable affected.

Figure 1 shows a causal loop diagram for a mitigation scenario regarding the impact of IMO regulatory changes on the shipping industry at an international scale. It reveals that regulation changes will require the ship owner to modify vessels, the costs of which involves a financial risk. Modifications to vessels will also then effect the company's policy on chartering vessel from the spot market. On the other hand, decisions to modify the vessels or a vessel scraping if the modification is not cost effective may also affect the availability of the fleet. Vessel scraping may also require a new building policy. Each scenario will have a financial impact on the company.

A causal loop diagram was then created specifically for a case company in Indonesia whose core business is the production of oil and gas and who operate a tanker vessel to distribute it thoughout Indonesia. Figure 2 below shows the causal loop diagram for this case study.

The causal loop diagrams focus on the impact of regulatory changes on freight costs, as freight is the main core variable in the shipping industry. Freight is a carriage or transportation cost of cargo that is paid by the charterer to the tanker owner. In the analysis, the effect of regulation change on freight is influenced by three main factors, capital expenditure (capex), operating expenditure (opex) and 
voyage cost, mainly because regulatory changes will cause additional costs for both freight costs and bunkers, ship instruments as well additional crew cost. In the causal loop diagram, regulatory changes show a positive link, because the effect of regulatory changes will always increase freight costs and other variables. The next step is to interpret this causal loop diagram into a stock and flow diagram (model) using system dynamic software, and then run the model simulation.
The simulation model runs within fourteen years, starting from 2006 to 2019 with a step per day. For minimizing inequality between ship categories, ship population os divided into 3 clusters namely:

1. General Purposes (GP) - 2 ships

2. Medium Range (MR) - 7 ships

3. Large Range $(L R)-5$ ships

The simulation is run by inputting each value from Figure 4 into a combined stock and flow diagram.

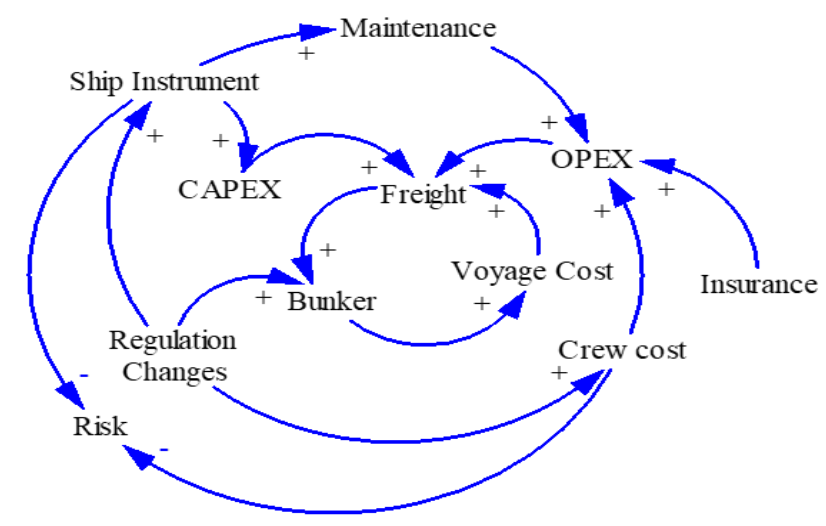

Figure 2 Causal loop diagram on case company

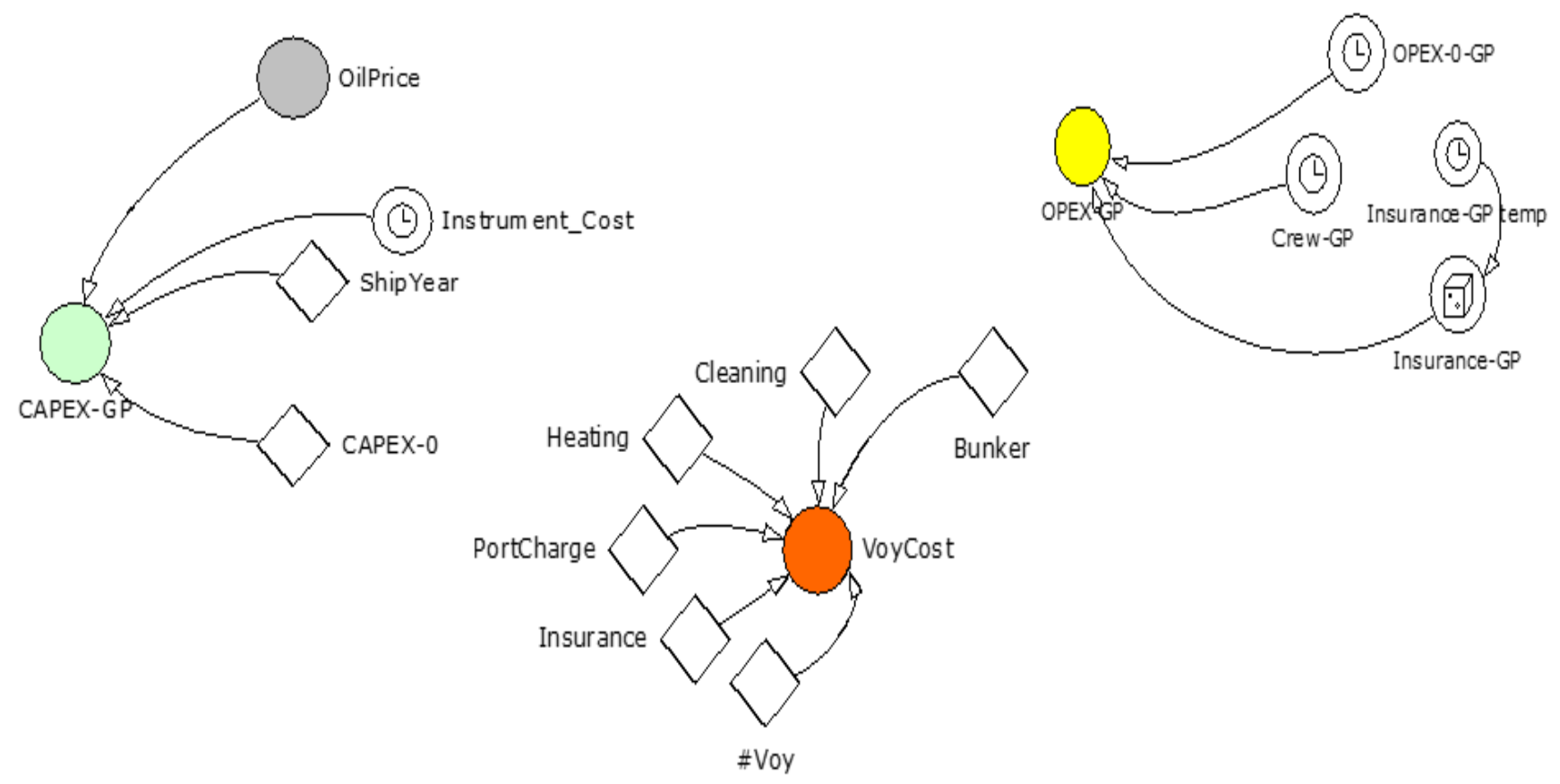

Figure 3 Stock and flow diagram 


\begin{tabular}{|c|c|c|c|}
\hline \multirow{2}{*}{ No } & \multirow{2}{*}{ Description } & \multirow{2}{*}{ Unit } & \multirow[t]{2}{*}{ GP } \\
\hline & & & \\
\hline 1 & H \& M INSURANCE & USD/Yeat & $55,440.00$ \\
\hline \multirow[t]{2}{*}{2} & PI INSURANCE & USD/Year & $25,906.50$ \\
\hline & & & $81,346.50$ \\
\hline 3 & Docking & USD/Year & 543.82 \\
\hline 4 & Jumlah Kapal & Ship & 2 \\
\hline 5 & Average Voyage/ year & Voy & 26 \\
\hline 6 & Ship price/unit & USD/Unit & $2,520.55$ \\
\hline 7 & OPEXX 0 & USD/Year & $2,318.76$ \\
\hline 8 & Repaif & USO/Yeat & 966.94 \\
\hline & & & \\
\hline 9 & Oill Price & USO/Year & $s$ \\
\hline 10 & Bunker & USD/Year & S $1,094,397,00$ \\
\hline 11 & Cleaning & USD/Year & S $\quad 49,847.00$ \\
\hline 12 & Heating & USD/Year & s $\quad 66,170.00$ \\
\hline 13 & Port Charge & USD/Year & S $1,167,400.00$ \\
\hline 14 & Voyage insurance & USD/Yeat & $\$$ \\
\hline 15 & Cost-Day-crew & USD/Day & 8.20000 \\
\hline 16 & Crew-Cert (Jumlah crew) & $p$ & 7 \\
\hline 17 & Cert (Jumlah sertifikat) & Cert & 17 \\
\hline 18 & Day-Cert & Day & 4 \\
\hline 19 & Ship year & & 3 \\
\hline
\end{tabular}

\begin{tabular}{|c|c|c|c|}
\hline \multirow{2}{*}{ No } & \multirow{2}{*}{ Description } & \multirow{2}{*}{ Unit } & \multirow{2}{*}{$\frac{M R}{N}$} \\
\hline & & & \\
\hline 1 & H\& M INSURANCE & USD/Year & $83,065.29$ \\
\hline 2 & PIINSURANCE & USD/Year & $28,177.00$ \\
\hline & & & $111,242.29$ \\
\hline 3 & Docking & USD/Year & 895.48 \\
\hline 4 & Jumlah Kapal & Ship & \\
\hline 5 & Average Voyage/ vear & Voy & 2 \\
\hline 6 & Ship price/unit & USO/Unit & $4,027.40$ \\
\hline 7 & OPEX 0 & USD/Year & $3,496.59$ \\
\hline 8 & Repair & USD/Year & $1,286.43$ \\
\hline 9 & Oil Price & USD/Year & $\$$ \\
\hline 10 & Bunker & USD/Year & $926,028.00$ \\
\hline 11 & Cleaning & USD/Year & $107,502.00$ \\
\hline 12 & Heating & USD/Year & $72,990.00$ \\
\hline 13 & Port Charge & USD/Year & \$ $1,152,800.00$ \\
\hline 14 & Voyage insurance & USD/Year & 5 \\
\hline 15 & Cost-Day-crew & USD/Day & $9,100.00$ \\
\hline 16 & Crew-Cert (Jumlah crew) & $p$ & \\
\hline 17 & Cert (Jumlah sertifikat) & Cert & 1 \\
\hline 18 & Day-Cert & Day & \\
\hline 19 & Ship year & & \\
\hline
\end{tabular}

\begin{tabular}{|c|c|c|c|}
\hline \multirow{2}{*}{ No } & \multirow{2}{*}{ Description } & \multirow{2}{*}{ Unit } & \multirow{2}{*}{$\frac{L R}{N}$} \\
\hline & & & \\
\hline 1 & H \& M INSURANCE & USD/Year & $117,204.80$ \\
\hline 2 & PI INSURANCE & USO/Year & $94,294.40$ \\
\hline & & & 211.499 .20 \\
\hline 3 & Dodking & USO/Year & 1.791 .04 \\
\hline 4 & Jumlah Kapal & Ship & 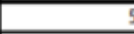 \\
\hline 5 & Average Voyase/ vear & Voy & 22 \\
\hline 6 & Ship price/unit & USD/Unit & $6,739.73$ \\
\hline 7 & OPEXOO & USD/Year & $9,054,41$ \\
\hline 8 & Repair & USD/Year & $2,509.15$ \\
\hline 9 & Oil Price & USD/Year & $s$ \\
\hline 10 & Bunket & USD/Year & S $2,685,350.00$ \\
\hline 11 & Cleaning & USO/Year & $5 \quad 131,847.00$ \\
\hline 12 & Heating & Uso/Year & $\$ \quad 90,520.00$ \\
\hline 13 & Port Charge & USD/Year & \$ $1,317,800.00$ \\
\hline 14 & Voyage Insurance & USD/Year & $\$$ \\
\hline 15 & Cost-Day-crew & USD/Day & $10,700.00$ \\
\hline 16 & Crew-Cert (Jumlah crew) & $p$ & 7 \\
\hline 17 & Cert (Jumlah sertifikat) & Cent & 17 \\
\hline 18 & Dar-Cert & Day & 7 \\
\hline 19 & Ship yeat & & 5 \\
\hline
\end{tabular}

Figure 4 Variable cost for GP, MR and LR tanker at case company

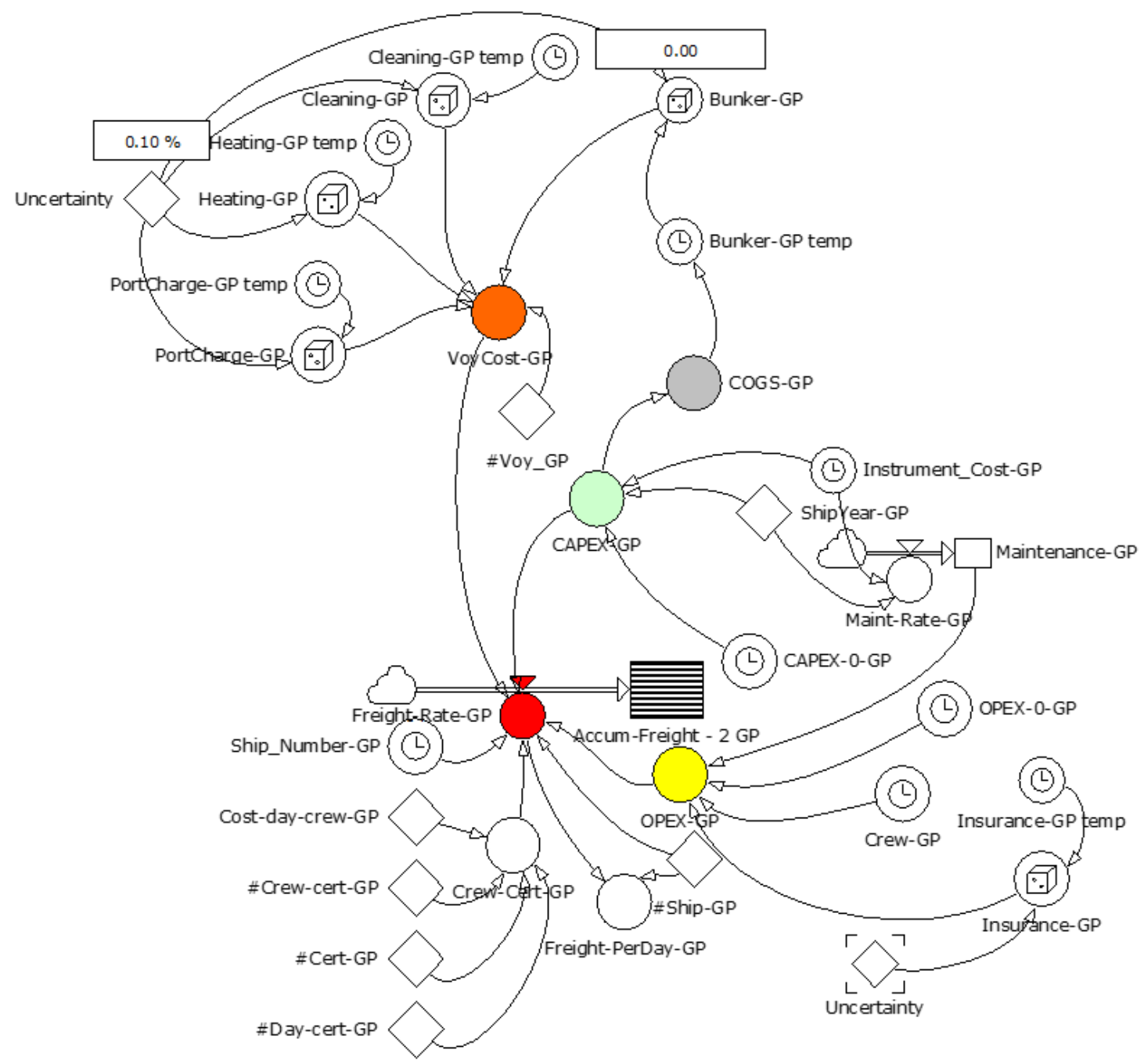

Figure 5 Combined stock and flow diagram 


\section{RESULTS \& DISCUSSION}

The data of regulatory obtained from ASB Future IMO legislation document of MSC74 to MSC95 issued by IMO. The document contains international maritime regulatory changes during 2006-2019. Regulation changes consists of SOLAS, MARPOL, Load Line and STCW. Data of regulatory changes used to all types of ship, but in this research focused only on international maritime regulation for tanker ship. After elimination for relevant case, there are 125 regulatory changes and 83 regulation is mandatory to tankers. Data regarding the number of regulatory changes was analyzed according to the area of impact, which includes ship instrument/construction, operation ship, cargo ship, crew/person on board, environment and security. According to (Leggate, et al., 2005) the effect of changes in maritime regulations can be classified according to the impact area. Impact area is kind influence / impact resulting from changes in maritime regulations. Impact due to changes in regulation of the maritime area consists of; are on ship instrument/construction, operation ship, cargo ship, crew/person on board, environment and security.

Table 2 shows that 66 regulatory changes have had an effect on instruments, 17 on operation. 2 on cargo. 4 on crew and 1 on environment, and there are none of these regulatory changes have impacted security.

Table 2 Total regulation changes impact area during 2006 to 2019 based on ABS issues of future IMO legislation

\begin{tabular}{ccccccc}
\hline Regulation & $\begin{array}{c}\text { Total of } \\
\text { regulatory } \\
\text { changes }\end{array}$ & $\begin{array}{c}\text { Ship } \\
\text { Instrument }\end{array}$ & $\begin{array}{c}\text { Ship } \\
\text { Operation }\end{array}$ & Cargo $\begin{array}{c}\text { Crew } \\
\text { of } \\
\text { ship }\end{array}$ & Environment \\
\hline SOLAS & 71 & 58 & 13 & 1 & 2 & 1 \\
MARPOL & 8 & 8 & 2 & 1 & - & - \\
STCW & 4 & - & 2 & - & 2 & - \\
$\begin{array}{c}\text { Total impact } \\
\text { area }\end{array}$ & 83 & 66 & 17 & 2 & 4 & 1 \\
\hline
\end{tabular}

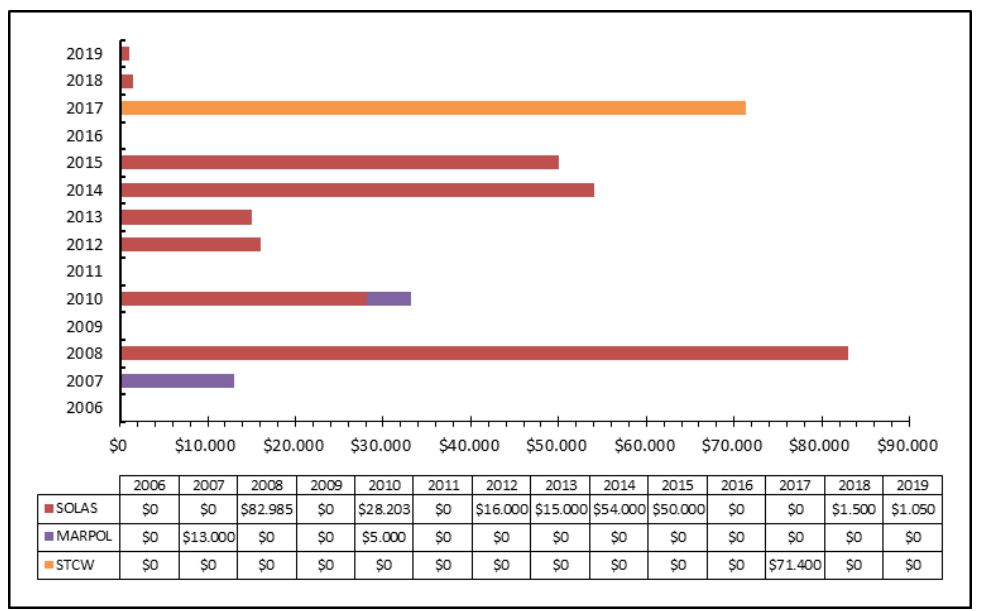

Figure 6 Financial impact on SOLA, MARPOL and STCW during 2006 - 2019

Table 3 Ship owned by case company

\begin{tabular}{lccc}
\multicolumn{1}{c}{ Name of Tanker ships } & DWT & Year of Built & Type \\
\hline MT.SEI PAKNING & 29755 & 2011 & MR \\
\hline MT.SAMBU & 29755 & 2011 & MR \\
\hline MT.SANGGAU & 40600 & 2015 & MR \\
\hline MT.GAMKONORA & 88312 & 2013 & LR \\
\hline MT.SUNGAI GERONG & 29755 & 2012 & MR \\
\hline MT.SENIPAH & 29754 & 2013 & MR \\
\hline MT.SANANA & 40600 & 2015 & MR \\
\hline MT.GUNUNG GEULIS & 107538 & 2009 & LR \\
\hline MT.SERUI & 40600 & 2015 & MR \\
\hline MT.GEDE & 88312 & 2010 & LR \\
\hline MT.GAMSUNORO & 105638 & 2014 & LR \\
\hline MT.GAMALAMA & 88312 & 2011 & LR \\
\hline MT.PANGKALAN BRANDAN & 17400 & 2014 & GP \\
\hline MT.PAGERUNGAN & 14454 & 2014 & GP \\
\hline
\end{tabular}


Table 4 Instrument cost for tanker vessel at case company

\begin{tabular}{cccccccc}
\hline Year & SOLAS & MARPOL & STCW & Total Compliance Cost & General Purpose (GP) & Medium Range (MR) & Long Range (LR) \\
\hline 2006 & $\$ 0$ & $\$ 0$ & $\$ 0$ & $\$ 0$ & $\$ 0$ & $\$ 0$ & $\$ 0$ \\
\hline 2007 & $\$ 0$ & $\$ 13,000$ & $\$ 0$ & $\$ 13,000$ & $\$ 0$ & $\$ 0$ & $\$ 0$ \\
\hline 2008 & $\$ 83,000$ & $\$ 0$ & $\$ 0$ & $\$ 83,000$ & $\$ 0$ & $\$ 0$ & $\$ 0$ \\
\hline 2009 & $\$ 0$ & $\$ 0$ & $\$ 0$ & $\$ 0$ & $\$ 0$ & $\$ 0$ & $\$ 0$ \\
\hline 2010 & $\$ 28,000$ & $\$ 5,000$ & $\$ 0$ & $\$ 33,000$ & $\$ 0$ & $\$ 0$ & $\$ 66,405$ \\
\hline 2011 & $\$ 0$ & $\$ 0$ & $\$ 0$ & $\$ 0$ & $\$ 0$ & $\$ 0$ & $\$ 0$ \\
\hline 2012 & $\$ 16,000$ & $\$ 0$ & $\$ 0$ & $\$ 16,000$ & $\$ 0$ & $\$ 48,000$ & $\$ 64,000$ \\
\hline 2013 & $\$ 15,000$ & $\$ 0$ & $\$ 0$ & $\$ 15,000$ & $\$ 0$ & $\$ 60,000$ & $\$ 75,000$ \\
\hline 2014 & $\$ 54,000$ & $\$ 0$ & $\$ 0$ & $\$ 54,000$ & $\$ 108,000$ & $\$ 216,000$ & $\$ 270,000$ \\
\hline 2015 & $\$ 50,000$ & $\$ 0$ & $\$ 0$ & $\$ 50,000$ & $\$ 100,000$ & $\$ 350,000$ & $\$ 250,000$ \\
\hline 2016 & $\$ 0$ & $\$ 0$ & $\$ 0$ & $\$ 0$ & $\$ 0$ & $\$ 0$ & $\$ 0$ \\
\hline 2017 & $\$ 0$ & $\$ 0$ & $\$ 72000$ & $\$ 72000$ & $\$ 144,000$ & $\$ 499,800$ & $\$ 357,000$ \\
\hline 2018 & $\$ 1,500$ & $\$ 0$ & $\$ 0$ & $\$ 1,500$ & $\$ 3,000$ & $\$ 10,500$ & $\$ 7,500$ \\
\hline 2019 & $\$ 1,050$ & $\$ 0$ & $\$ 0$ & $\$ 1,050$ & $\$ 2,100$ & $\$ 7,350$ & $\$ 5,250$ \\
\hline
\end{tabular}

$\underline{\text { Table } 5 \text { Total financial impact for each tanker type owned by case company }}$

\begin{tabular}{cccccc}
\hline No & $\begin{array}{c}\text { Type of } \\
\text { tanker }\end{array}$ & $\begin{array}{c}\text { Implementation/Instrument } \\
\text { Cost }\end{array}$ & Total Service cost & $\begin{array}{c}\text { Total Maintenance } \\
\text { Cost (ship lifecycle) }\end{array}$ & Total Consequence \\
\hline 1 & GP & $\$ 355,900$ & $\$ 17,795$ & $\$ 939,576$ & $\$ 1,313,271$ \\
\hline 2 & MR & $\$ 1,191,650$ & $\$ 59,583$ & $\$ 1,511,693$ & $\$ 2,762,926$ \\
\hline 3 & LR & $\$ 1,095,155$ & $\$ 54,758$ & $\$ 1,274,760$ & $\$ 2,424,673$ \\
\hline \multicolumn{7}{r}{} \\
\hline
\end{tabular}

The consequence of the changes is determined by estimating implementation costs from interviews with experts in shipping finance. Figure 3 illustrates the total cost required to comply with the total of 83 regulations that changed during 2006-2009. For instance, 338,138 USD compliance cost must added to capital expenditure.

In addition, the implementation costs of regulatory changes to MARPOL and STCW did not significantly change during this period. The most significant impact of regulatory changes on MARPOL occurred in 2006, which is when the IMO enforced the single hull to double hull regulation. The compliance cost for every year is then calculated based on tanker type. Table 3 show the name of tanker ship owned by case company and Table 4 illustrates the instrument cost or compliance cost for each vessel.

After calculating implementation costs, the total costs faced by the case company are illustrated in Table 4 . Two type of costs need to be expended by the shipping company to comply with maritime regulations, namely initial costs and annual costs. (UNCTAD, 2007) The financial impact can be calculated by summarizing the initial cost and annual cost. Further, annual costs are divided into maintenance costs and service costs, respectively $6 \%$ and $5 \%$ from initial costs (Smith, 2015). Based on Table 5, the total consequences for each ship type show different values. Consecutively, the value of the consequence on General Purpose (GP) vessels is 1.3 million USD, while the Medium Range (MR) vessel of 2.7 million USD and the last for Large Range (LR) vessels has a consequent value of 2.4 million USD. The difference in the value of these consequences is due to the number, size and type of vessel. The calculation shows the average value of total financial impact as 6.5 million USD. Therefore, the average financial impact found as 6.5 million USD considered as "Insignificant" to case company business according to criteria rating in Table 6.

Table 6 Criteria rating (Consequence)

\begin{tabular}{ccc}
\hline No & Criteria & $\begin{array}{l}\text { Financial Impact } \\
\text { (thousand USD) }\end{array}$ \\
\hline 1 & Insignificant & $0<x \leq 685$ \\
\hline 2 & Minor & $685<x \leq 1370$ \\
\hline 3 & Moderate & $1370<x \leq 2056$ \\
\hline 4 & Significant & $2056<x \leq 2741$ \\
\hline 5 & Cathastropic & $x>2741$ \\
\hline
\end{tabular}

Source: case company

The last step is to determine the likelihood by calculating the average frequency of regulatory change per year. The total regulation change ( 83 regulations) is divided with interval period from 2006-2019 (12 years). Therefore, there are nearly seven regulatory changes in average affecting oil tankers per year and this value is considered as "likely" based on the likelihood criteria in Table 7.

Table 7 Criteria rating (Likelihood)

\begin{tabular}{ccc}
\hline No & Regulation change per year & Likelihood Criteria \\
\hline 1 & $1-2$ & Rare \\
\hline 2 & $3-4$ & Unlikely \\
\hline 3 & $5-6$ & Moderate \\
\hline 4 & $7-8$ & Likely \\
\hline 5 & $9-10$ & Almost \\
\hline 6 & $>10$ & Definietly \\
\hline
\end{tabular}

Source: case company 
Table 8 Risk register standard of case company

\begin{tabular}{|c|c|}
\hline RPN Range & Criteria \\
\hline$(15-30)$ & Catastrophic \\
\hline$(8-12)$ & Significant \\
\hline$(4-6)$ & Moderate \\
\hline$(2-3)$ & Minor \\
\hline (1) & Insignificant \\
\hline
\end{tabular}

\begin{tabular}{|c|c|c|c|c|c|c|c|}
\hline \multirow{5}{*}{$\begin{array}{l}\xi \\
\xi \\
\sum\end{array}$} & 5 & Moderate & Significant & Catastrophic & Catastroph ic & Catastroph ic & Catastrophic \\
\hline & 4 & Moderate & Significant & Significant & Catastroph ic & Catas troph ic & Catastrophic \\
\hline & 3 & Minor & Moderate & Significant & Significant & Catas troph ic & Catastrophic \\
\hline & 2 & Minor & Moderate & Moderate & Significant & Significant & Significant \\
\hline & 1 & Insign ific ant & Minor & Minor & 1 & Moderate & Moderate \\
\hline & & 1 & 2 & 3 & 4 & 5 & 6 \\
\hline & & & & LIKEI & HOOD & & \\
\hline
\end{tabular}

Figure 7 Risk matrix of case company

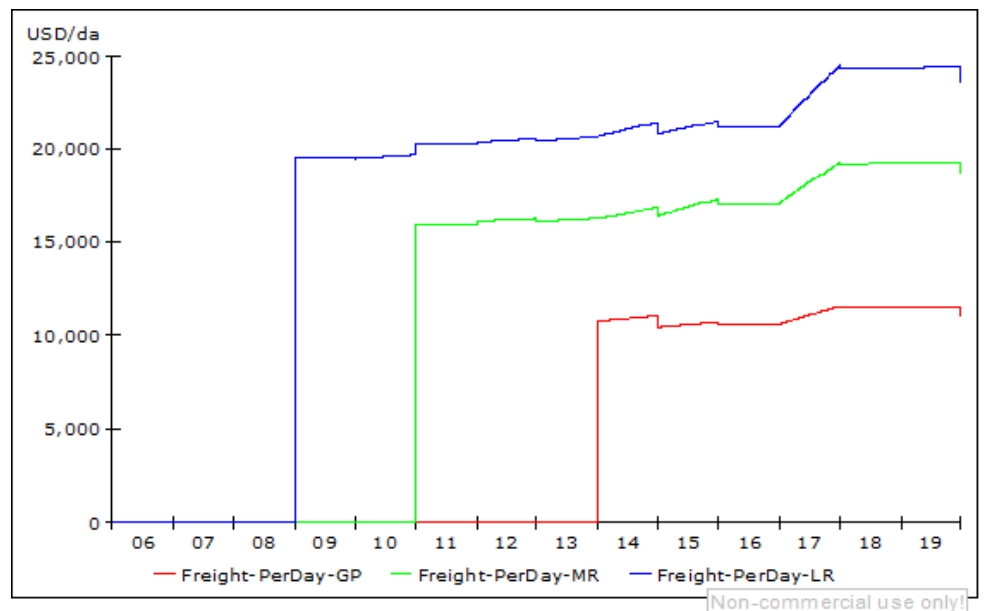

Figure 8 Freight rat eper day for ship category GP, MR, and LR within the period of 14 year

Finally, the last step is to evaluate how IMO's regulatory changes impact on the business by using a risk register. The result of multiplication criteria between consequence and frequency is formulated into a risk matrix to obtain the Risk Priority Number (RPN). Figure 7 reveals that the risk from maritime regulation change is "Moderate" in the case of this company.

$$
\begin{array}{ll}
\mathrm{RPN} & =\mathrm{C} \times \mathrm{F} \\
\mathrm{RPN} & =1 \times 4 \\
\mathrm{RPN} & =4
\end{array}
$$

\section{CONCLUSION}

Results of this study reveal that regulatory changes can be a financial risk for the shipping industry. This conclusion is based on a risk assessment conducted in case company where the risk was categorized as catastrophic to their business. Moreover, the more ships owned by a shipping company will increase the financial impact of regulatory changes. The results from system-dynamics modelling show that regulation changes affect the spot-charter variable in the freight market. 
This method has revealed that the freight rate from year to year has increased significantly. Freight per day varies greatly for each category of vessel, especially in 2010 until 2015 , which is the result of regulatory changes that are applicable to the three categories of vessels. But when viewed from its value, such is not significant enough because less than \$500.

The response of ship owners to mitigating the risks of regulatory changes, such as increasing their charter rates, has financial consequences for other players in the maritime industry. Moreover, the total changes that are occurring in regulations on an annual basis is increasing, which will affect the total cost of building new ships and thus have financial consequences for other industries. The findings of this research and its methods can be used by shipping companies, who are the most exposed to the financial risks imposed by regulatory changes in maritime regulations. They could use the proposed risk assessment method to calculate this financial impact and thereafter use it for their own risk register.

\section{ACKNOWLEDGEMENT}

This work is part of a dissertation project that is being conducted by the first author as part of the doctoral program offered by the Faculty of Marine Technology of Institut Teknologi Sepuluh Nopember Surabaya (ITS). Special appreciation to Lahar Baliwangi as Risk and Safety Lead Engineer at Bureau Veritas, Kuala Lumpur, Malaysia for discussion in system-dynamics model.

\section{REFERENCES}

Alderton, P. \& Leggate, H. (2005). The surge in regulation. In: H. Leggate, J. McConville \& A. Morvillo, eds. International Transportation Maritime Perspective. New York: Routledge, pp. 249-260.

Alizadeh, A., Huang, C.-Y. \& Dellen, S. (2015). A regime switching approach for hedging tanker shipping freight rates. Energy Economics, 49(1), pp. 44-59.

Andreou, P., Louca, C. \& Panayides, P. (2014). Corporate governance, financial management decisions and firm performance: Evidence from the maritime industry. Transportation Research Part E, 63(1), pp. 59-78.

Ben-Asher, J., 2008. Development Program Risk Assessment based on Utility Theory. Risk Management, 10(1), pp. 285-299.

E.Eliopoulu \& N.Mikelis. (2015). The Influence of Regulations on the Safety Record of the Aframax Tankers, Athens: Research Gate.

Grammenos, C. T. (2010). The Handbook of Maritime Economics and Business. 2nd ed. London: MPG Books Ltd.

Horn, G., Marshall, G., Rynn, P. \& Stanton, M. (2008). Tanker safety: Regulatory change. WMU Journal of Maritime Affairs, 7(1), pp. 317-351.

IMO (2000). Objectives of the Organization in the 2000s, Resolution A.900 (21), London: IMO Publishing.

Karahalios, H. (2015). The Management of Maritime Regulations. 1st ed. Abingdon: Routledge.

Karahalios, H., Yang, Z., Williams, V. \& Wang, J. (2011). A proposed system of hierarchical scorecards to assess the implementation of maritime regulations. Safety Science, 49(1), pp. 450-462.

Klikauer, T. \& Morris, R. (2003). Human resources in the German maritime industries:'back-sourcing' and ship management. International Journal of Human Resource Management, 14(4), pp. 544-558.

Knapp, S. \& Franses, P. (2009). Does ratification matter and do major conventions improve safety and decrease pollution in shipping?. Marine Policy, 33(1), pp. 826-846.

Lylod's Register. (2016). Future IMO Legislation, London: Lyliyd's Register EMEA.

Mitroussi, K. (2004). Quality in shipping: IMO's role and problems of implementation. Disaster Prevention and Management: An International Journal, Volume 13, pp. 50-58.

Neser, G., Unsalan, D., Tekogul, N. \& Stuer-Lauridsen, F. (2008). The shipbreaking industry in Turkey: environmental, safety and health issues. Journal of Cleaner Production, 16(1), pp. 350-358.

Progoulaki, M. \& Theotokas, I. (2010). Human resource management and competitive and advantage: an application of resource-based view in the shipping industry. Marine Policy, 34(1), pp. 575-582.

Rigaud, E. et al. (2012). IMPACT: more than maritime risk assessment. Transport Research Arena, 48(1), pp. 18481854.

Soares, C. \& Teixeira, A. (2001). Risk assessment in maritime transportation. Reliability Engineering \& System Safety, 74(1), pp. 299-309.

Song, D.-W. \& Panayides, P. (2012). Maritime Logistics: A Complete Guide to Effective Shipping and Port Management. 1st ed. Great Britain: Kogan Page.

Sterman, J. (2004). Business Dynamics. 1st ed. Massachusett: Irwin McGraw-Hill.

T.Grammenos, C. \& Choi, C. J. (2014). The Greek shipping industry: Regulatory change and evolving organizational forms. International Studies of Management \& Organizations, Volume 29, pp. 34-52.

Tsai, M., Regan, A. \& Saphores, J. (2009). Freight transportation derivatives contracts: state of the art and future developments. Transportation Journal, 48(1), pp. 7-19.

UNCTAD. (2015). Review of Maritime Transport, New York: United Nation Publication.

Wang, J. (2006). Maritime risk assessment and its current status. Quality and Reliability Engineering International, 22(1), pp. 3-19.

Pratomo Setyohadi is a professional manager in oil and gas transportation in Indonesia, working for Pertamina since 1990. His activity covers maritime logistics, shipping operation, ship management, oil and gas supply chain. He obtained PhD degree from ITS. His research focuses on maritime regulations since shipping is heavily regulated.

Ketut Buda Artana is Professor in the Department of Marine Engineering, Institut Teknologi Sepuluh Nopember (ITS) in Surabaya, Indonesia. He obtained Bachelor degree from ITS, Master degree from University of Newcastle Upon Tyne, UK and Doctorate degree from Kobe University of Mercantile Marine, Japan. His interest is in Reliability Engineering, Safety of Marine Systems, and Risk Assessment for Marine Systems.

Djauhar Manfaat was a professor in Marine Technology Faculty of Sepuluh Nopember Institute of Technology (ITS) in Surabaya Indonesia. 
Raja Oloan Saut Gurning currently works as a senior lecturer in Marine Technology Faculty of Sepuluh Nopember Institute of Technology (ITS) in Surabaya Indonesia. After his PhD in maritime logistics at Australian Maritime College (AMC), University of Tasmania - Australia, he continues his research and research on maritime logistics, supply chain risk management, port operations and management. In Indonesia, he also intensively involves in a lot of professional assignments in relation to bulk cargo operations, cargo handling equipment, drafting and implementing shipping and port national regulations, assessment of business risk management of various maritime related enterprise in Indonesia. 